\title{
The Role of Sarangan Asri Cooperation in Increasing Cadger's Income In Tourism Village Of Sarangan Lake Slope of Lawu Mountain
}

\author{
Bara Septian Laraswati \\ Graduate School \\ Universitas Negeri Yogyakarta \\ Yogyakarta, Indonesia \\ bara.septian2016@student.uny.ac.id
}

\author{
Sugiharsono \\ Graduate School \\ Universitas Negeri Yogyakarta \\ Yogyakarta, Indonesia \\ sugiharsono@uny.ac.id
}

\begin{abstract}
The purpose of this research is to know the role of Cooperative Sarangan Asri in increasing the income of street hawkers in Sarangan Lake Tourism Village. This research uses qualitative research methods, because researchers want to know the extent of business activities developed. This case study was conducted by Sarangan Asri Cooperation, the role the role of Sarangan Asri cooperation in increasing cadger's around Sarangan tourism, and any constraints in increasing the income of street hawkers around Sarangan Lake tourism through cooperatives. The collection data techniques: Observation, Interview and Documentation. The results showed that the Role of Cooperation is very helpful for most of the Cadger's in tourism village of Sarangan lake slope of Lawu Mountain.
\end{abstract} Income

Keywords- Sarangan Asri Cooperation, Cadger's,

\section{INTRODUCTION}

Sarangan Asri Cooperation has a role, among others, providing loans or capital credit to its members equal to 10 million members. The loan is used by members for capital in trading. This cooperation also provides coaching to its members in the form of training and scientific meeting. This guidance aims to improve the understanding of members in the management of trading business, for example in terms of marketing and packaging of products. Although the cooperative has done capital lending and various coaching, but the impact on income or welfare street vendors in Sarangan not yet known. Until now, the income of street vendors is still relatively low. Based on the results of interviews with one of the vegetable vendors obtained information that income is still very less in meeting the needs of his family for one month. "Yes, still about 1.3 million every month, it's still not pays for my child's tuition fee every month" (interview with SM). Related to these problems, Sarangan cooperative has tried to solve the problem. But until now unknown impact of the role of cooperatives. There are indeed many supporting factors as well as inhibiting cooperatives in supporting the development of business PKL as its members. But the supporting and inhibiting factors of cooperative coaching efforts are also not known for certain. Therefore, this research wanted to try to see the impact of the existence of the street vendor cooperative to the income of the street vendors which until now unknown. Therefore, it is necessary to know how the role of Sarangan village cooperative in increasing the income of street vendors in Sarangan tourist village area.

The income of street vendors that fluctuate, street vendors are generally lack of capital, the income of street vendors is still relatively low, there are cooperatives as a container of economic activities of street vendors but not yet clear role, not known factors supporting or hampering cooperatives in fostering street vendors in Sarangan. Related to these problems, Sarangan cooperative has tried to solve the problem. But until now unknown impact of the role of cooperatives and how many factors supporting and inhibiting cooperatives in supporting the development of business PKL as its members. But the supporting and inhibiting factors of cooperative coaching efforts are also not known for certain.

Problem Statement in this research is: 1) How is the role of cooperative "Sarangan Asri" in increasing the income of street vendors in Sarangan village? 2)What are the factors driving and inhibiting cooperative "Sarangan Asri" in increasing the street vendors in the village Sarangan? This research aims to: 1) To know the role of cooperative "Sarangan Asri" in increasing the income of street vendors in Sarangan village. 2) To know the factors driving and inhibiting cooperative "Sarangan Asri" in increasing the street vendors in the village Sarangan. This research is limited to the problem: The role of cooperative "Sarangan Asri" in increasing the income of street vendors in Sarangan village and the factors driving and inhibiting cooperative "Sarangan Asri" in increasing the street vendors in the village Sarangan.

\section{THEORETICAL REVIEW}

This study aims to determine the role of street vendor cooperatives in increasing the income of street vendors in the village of Sarangan Lake tourism. Study theory in research is needed for research has a solid 
foundation, the study of the theory to be discussed cannot be separated from the focus of research. The focus of the study of the theories we discussed includes: Cooperatives, Trades and Revenue. As well as relevant research studies, thought processes and research questions.

Cooperatives are a collection of people and not a collection of capital. Cooperatives must be dedicated to the interests of humanity solely and not to the material. Cooperation in cooperatives is based on a sense of equality, and awareness of its members. Cooperative is a container of economic and social democracy. Cooperatives are jointly owned by members, administrators and managers. The business is arranged in accordance with the wishes of the members through the meeting members.

Cooperative aims to promote the welfare of members and society in general and participate in building the order of the national economy in order to realize a developed, just and prosperous society based on Pancasila and the 1945 Constitution.

The form of cooperatives based on Law number. 25 of 1992 recognizes 2 forms of cooperatives namely primary cooperatives and secondary cooperatives. The primary cooperative is a cooperative founded by and consisting of a person. Secondary cooperatives are cooperatives established by cooperative members. Regarding the formation requirements, primary cooperatives are formed by at least 10 people. Secondary cooperatives are formed by at least 3 cooperatives.

A street vendor is a person who with relatively little capital in the field of production and sales of goods (services) to meet the needs of a group within society, the business is carried out in places deemed strategic in an informal environment [2]. Street vendors are generally self-employed, meaning that most street vendors consist of only one workforce. Capital owned relatively not too large, and divided into fixed capital, in the form of equipment, and working capital. Such funds are rarely met from official financial institutions, usually from illegal sources of funds or from suppliers who supply merchandise. While the source of funds derived from the savings themselves very little. This means that only a few of them can put aside their business results, due to the low rate of profit and the way money is managed. So, the possibility to make capital investment and business expansion is very small [8].

Understanding of informal sector traders is closely related to the informal economy. Most informal enterprises consist of legitimate economic activities with weak institutions and organizations, the informal sector consists of legitimate commercial activities such as food stalls, street clothing sellers and others with no legal requirements, such as having to have a license and pay taxes.

According to Jay M. Smith and K. Fred Skosen define income as follows: "Revenue is the cash inflows or other additions to the assets of an entity or the settlement of its obligations (a combination of both) derived from the production or production of goods, the provision of services, or other activities which constitute the principal operation or ongoing core operations of an entity" [1]. Revenue is an important thing in the operation of a company, because in conducting a business activity, the company will expect profits that are affected by revenue from the activity. Revenue is also a factor to ensure survival and a measure of the success of a company in carrying out its operations.

\section{METHODOLOGY}

\section{A. Kind of Research}

In completing this study, researchers used a descriptive qualitative approach. That is, the data collected is not in the form of numerical data, but rather data derived from interview texts, field notes, personal documents, researchers' notes or memos and other official documents that support. The purpose of using a qualitative approach is so that researchers can describe the empirical reality behind the phenomenon happened related to the role of the beautiful Sarangan cooperative in increasing the income of street vendors in the tourist village of Sarangan Lake.

\section{B. Place and Time Resarch}

The location that became the object of this research is Sarangan Lake Tours located in Sarangan Village, Plaosan district, Magetan district of East Java. Research is done in December to 2018 February. The subjects of this research are the officials of Sarangan cooperative and the hawkers of Sarangan who become its members. The subject of the research is then used as a source of data in addition to the existing documents on the cooperative Sarangan Asri. Data obtained from research subjects is primary data, while data from document is secondary data (complementary). The documents in need are various records and archives about the cooperative "Sarangan Asri".

\section{Technique and Data Collection Instrument}

In completing this study, researchers used a descriptive qualitative approach. That is, the data collected is not in the form of numerical data, but rather data derived from interview texts, field notes, personal documents, researchers' notes or memos and other official documents that support. The purpose of using a qualitative approach is so that researchers can describe the empirical reality behind the phenomenon happened related to the role of the beautiful Sarangan 
cooperative in increasing the income of street vendors in the tourist village of Sarangan Lake.

To obtain accurate data used several methods and data collection tools as follows:

\section{Observation}

In this study, researchers looked directly at the situation and atmosphere of the activities in the cooperative Sarangan Asri. The researcher performs observation and recording of data systematically to the elements that appear in a symptom on the object of research by looking at the guidelines as an instrument of observation aimed to examine the role of cooperatives in increasing the income of street vendors around the lake Sarangan. The author went directly to the research site by his own observation directly and observing himself, then recorded the behavior and events as happened at the time of buying and selling activities around the lake Sarangan. The authors do research, record and understand events in situations related to the knowledge directly obtained from the data in accordance with the observed focus, and later data obtained will be analyzed again. The observation stage aims to find out the profile of cooperative Sarangan Asri. The research instrument used the observation guidelines.

\section{Interview}

Researchers conducted interviews directly to informants in order to obtain data in research. Researchers at the time to conduct interviews with informants using tools such as mobile phones, pen, block notes, digital cameras. This interview was conducted in order to gain in-depth information on the role of the Sarangan cooperative in increasing the income of street vendors in the Sarangan lake. Researchers use data collection tools in the form of interview guidelines that are instruments in the form of questions addressed to informants. In this study, interviewees were informants who were the subjects of research and informants who were not the subject of the study. Informants of research subjects are board members and members of the cooperative Sarangan Asri. The results of interviews with Sarangan Asri cooperative board are about the activities undertaken in Sarangan Asri cooperative, the development of cooperatives, the role of cooperatives in increasing the income of street vendors and the constraints faced by cooperatives to increase the income of street vendors around the tour Sarangan. The research instrument used interview guidelines.

\section{Documentation}

Documentation is the collection of archives, books, photographs, as evidence showing events or activities related to this research. The document used in this research is a picture of cooperative activities of Sarangan Asri. The use of photographs as complementary data obtained through interviews; observations aimed at perpetuating events occurring in the field associated with the research. The documentation of the photograph was obtained from a personal photo depicting a business activity run by a street vendor in Sarangan Lake. Documentation research instrument in the form of documents in the form of archives and records about cooperative "Sarangan Asri"

\section{Technique of Validity Data and Analyzing Data}

Technique of analyzing data in this research consists of Bogdan \& Bike in describes data analysis is the work done through working with data, organizing data, sorting data into manageable data units, synthesizing data, searching and finding patterns, finding what matters and what learned, and decided what can be told to others [3].

Data analysis technique is done so that data obtained more meaningful. In qualitative research, data analysis is the process of simplifying the data into a form that is easier to read. Qualitative research considers the data as a product of the process of providing interpretation of researchers in which already contained a meaning that has a reference to the value.

Data analysis is the process of data simplification into a form that is easy to read and understand and related to the data obtained in the study. Data analysis techniques used to analyze is a qualitative analysis technique interactive model, as revealed by Miles and Hubberman, 1984 [4], namely:

\section{Data collection}

The data collection is done through various methods, namely observation, questionnaires, interviews, literature study, and documentation whose results are recorded in field notes about what is seen, heard, felt, witnessed, and what findings encountered during the study.

\section{Data reduction}

Data reduction is an election process, focusing attention on simplifying measures, abstracting, and transforming coarse data arising from written records in the field. Data reduction in this study is centered by selecting, simplifying or further refining, reinforcing, abbreviating, transforming rough data arising from information obtained in the field, and organizing data for conclusions to be drawn. Reduced data will also provide an overview that can make it easier for researchers to find back data needed later. Data reduction continues throughout the study.

\section{Presentation of data}

Presentation of data is a step to compile some information that has been obtained and provide possibilities to be drawn conclusions. Presentation of data conducted by researchers to facilitate researchers in understanding the results of research. 


\section{Conclusion / verification}

A conclusion is an attempt to seek or understand the meaning, the regularity of the explanatory patterns, the causal path or a proposition. Researchers seek to find the meaning behind the data generated in the research and analyze the data that continue to make conclusions. The conclusions drawn are immediately verified by looking and questioning again while looking at field notes to gain a more precise understanding.

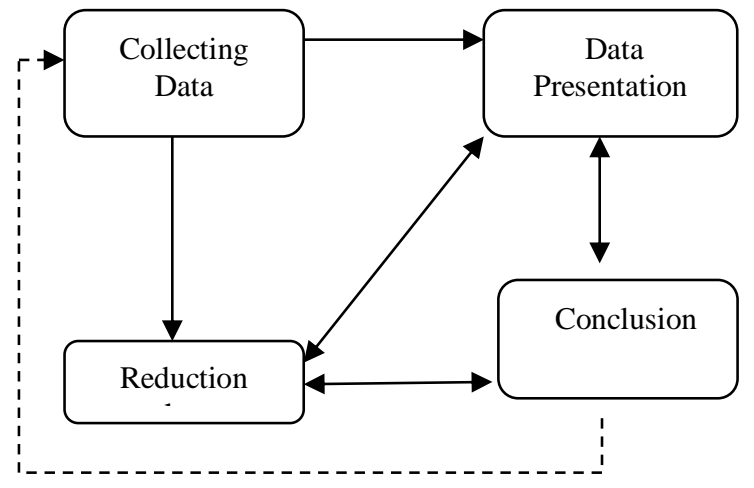

Fig. 1. Interactive Data Analysis Model of Milles and Hubberman

\section{Community facilities}

Cooperatives become micro economic institutions that serve to prosper the community, but now the government gives great attention to the cooperatives in Indonesia. This flagship program is intended to be a pillar of community economic motivation, so it is expected to reach up to the socio-economic level is low. Sarangan Asri Cooperation has one role as community gathering place. In this case the community represented by street vendors around the village in Sarangan. Sarangan Asri Cooperation holds associations in every three months to implement one of their activities namely transparency of funds in cooperatives and social gathering Fund transparency explains the money coming in and money out in every month and announces the members who often save. Social gathering held by only paying 100,000 per member, the result of this social gathering can be quite helpful to add capital. This association is followed by all members of the cooperative Sarangan Asri, but in every association is not all present. Members are present only about 100 people from 177 members who are members in the cooperative Sarangan Asri. because of their limited time to attend the monthly event of the cooperative. The location of each gathering event in one of the restaurants has a large hall that is in the villa and restaurant is fed. The arrangement of the event starts from the opening by the secretary, the welcome of the head of the cooperative as well as the announcement of the most saving members, the last social gathering and prayer.

\section{Increased resources (Members)}

What resources Increased resources for members within a street hawkers cooperative by way of providing training or coaching of the cooperative itself or from a government agency. As in January 2017, Sarangan cooperative cooperate with sub-district Sarangan and police in counseling the location of the sale or location on the edge of the lake Sarangan to look tidier and more comfortable in the view. In June there was a business management development by the Magetan district trade office where street vendors were given the knowledge of how good and more efficient management should be. In addition to coaching cooperation also held a holiday as well as study appeal to street vendors in Bandung about marketing, the event is right in July followed by all members and administrators Sarangan sarong. In November the cooperative held a workshop and invited Mr. Margono a successful businessman from Magelang who has experience in the field of packing products.

\section{Facilitator for members in venture capital.}

The facilitator for members in venture capital is a Sarangan cooperative for street hawkers. The cooperative provides credit funds for capital with the following provisions: Registered as a member of KSU "Sarangan Asri", Obeying the rules in the AD / ART KSU Sarangan Asri, Willing to pay Administration fee of $2 \%$. Willing to pay interest rate of $2 \%$ per month, installment payment at counter or paying stall in working hours, delay in installment will be imposed a fine of interest on that week, Timing of borrowing: loan less than 1 million in paid 3 months, loan 1.5 million to 2 million paid 6 months and loan more than 3 million in paid 1 year, loans above 5 million must use a guarantee letter.

\section{DISCUSSION}

The role of Sarangan cooperative in increasing the income of street vendors, giving loan or capital credit to its members up to 5 million. The loan is used by members for capital in trading. This cooperative also provides coaching to its members in the form of training and scientific meeting. This guidance aims to improve the understanding of members in the management of trading business, for example in terms of marketing and packaging of products. The form of co-operative development to members in cooperation with other agencies. the role of cooperatives is very helpful in increasing the income of street vendors.

The driving factor of the Sarangan cooperative in increasing the income of street vendors in Sarangan tourism village. In terms of skill enhancement, members are required to market their products, and use technology according to their merchandise. In this case the cooperative has another power because the cooperative can provide the possibility of introducing new technology through savings by obtaining information directly and available to every member who needs it. All that can be obtained for every street 
vendor who have decided to become members of the cooperative. They will more quickly obtain information quickly, for example through counseling related to business management, product packing and much more. Thus, if the cooperative can produce such benefits for its members will encourage people to cooperate because it is considered useful. Members are satisfied with the services provided by Sarangan Asri Cooperative in fulfilling the needs. Cooperatives expand their business area in the field of production which in addition to the benefits also increase the income for the welfare of its members, in addition to meet basic needs, also help parents who face the cost of education for their children. With the existence of this maximal cooperative service, it will make a meaningful contribution, in sustaining the economic needs of its members. They can use the financial services of the cooperative, without having to convoluted and not have to pawn important papers. Therefore, Sarangan Asri Cooperative managed to provide good service to street vendors who become members.

The inhibitory factor of the Sarangan cooperative in increasing the income of street vendors in Sarangan tourism village. Management is less mastering the use of computers in running a cooperative business. One of the disadvantages of Sarangan Asri Cooperative is the mastery in the use of technology members and less administrators. Because most administrators in Sarangan Asri Cooperative are only high school graduates, so tend not to be able to operate the computer. To increase their welfare in the administrative field, the board conducts the training first so that when many members are saving can be in excel data and they are no longer rigid in operating the computer, because the computer is one of the technology often used in completing a job.

From the results of the above research, it can be analyzed by using the theory of functionalism one of them Malinowski theory. In this study can be seen that the social system named Sarangan Asri analogous like organisms that have certain parts in which each part is interconnected and contributes to the maintenance of stability in the prosperity of society that basically human needs are the same, be it the needs of a biological as well as the psychological and cultural nature in essence to meet those needs. The condition of the fulfillment of needs cannot be separated from a dynamic process of change toward the construction of mutually agreed values in a society that is fulfillment of daily needs to achieve prosperity in their life and the impact of the value ultimately form the actions instituted through Cooperative activities Sarangan Asri. So, in the Cooperative Organization it intends to satisfy a series of several instincts of human beings related to all life that will be created an increase in welfare (income) of society that is either members or nonmembers of the Cooperative.

\section{CONCLUSION}

Based on the results of research and discussion on the above findings, it can be drawn the conclusion This research is one of the qualitative studies that describes the experience and meaning of the phenomena that occur in street vendors in Sarangan Wista Village. based on the results of the study can be concluded as follows: Based on the results of the research and discussion on the findings above, it can be concluded that the scope of the Sarangan Asri cooperative provides a very large role in increasing income for street vendors, especially in terms of capital and training. The driving factor and inhibitor of the Sarangan Asri cooperative in increasing the income of street vendors. In terms of skills improvement, here members are required to be able to market products and use technology in accordance with their merchandise. Administrators lack control over computer use in running cooperative businesses. One of the weaknesses of the Sarangan Asri Cooperative is the lack of mastery in the use of technology of members and administrators and the entrance ticket to Sarangan lake which increases to $150 \%$ resulting in a lack of tourists.

\section{REFERENCES}

[1] Amin Wijaya Tunggal. Dasar Dasar Analisis Laporan Keuangan. Jakarta: Rineka Cipt, 1995.

[2] Alisyahbana, Marginalisasi Sektor Informal Perkotaan. Surabaya: ITS Press, 2005.

[3] Ananta, Aris. Mengurai Akar Masalah Pedagang Kaki Lima. Yayasan Obor. Jakarta, 2002.

[4] Bogdan, Robert dan Steven Taylor. Pengantar Metode Kualitatif. Surabaya: Usaha Nasional, 1992.

[5] Chaniago, Arifinal. Pengertian dan Prinsip Koperasi. Jakarta: Salemba empat, 1984.

[6] Danisworo, Muhammad. "Keberadaan Pedagang Kaki lima sebagai Proses Perencanna Tata Ruang Kota" Makalah pada Diskusi Panel Pedagang Kaki lima. Bandung: ITB

[7] Eachern, William. Ekonomi Makro: Pendekatan Kontemporer. Jakarta: Salemba Empat, 2001.

[8] Hidayat, Peranan Sektor Informal dalam Perekonomian Indonesia, Ekonomi Keuangan Indonesia, Vol. XXVI, No.4, Desember, 1978, pp. 415 - 443.

[9] Haryono, Tulus, Faktor-Faktor Yang Mempengaruhi Keberhasilan Usaha Pedagang Kaki Lima : Studi Kasus di Kodya Surakarta (tesis yang tidak dipublikasikan), Pascasarjana Universitas Gadjah Mada, 1989.

[10] Jay M. Smith dan K.Fred Skosen. Akutansi Intermediated. Edisi kelimabelas di terjemahakan oleh Maulana Ahmad. Jakarta: Salemba Empat, 2005.

[11] Mulyanto. Pengaruh Motivasi dan Kemampuan Manajerial Terhadap Kinerja Usaha Pedagang Kaki Lima. Jurnal Manajemen dan Bisnis. Vol 11 No.1, 2007, pp. 73-86.

[12]Miles, B. Mathew dan Michael Huberman. Analisis Data Kualitatif Buku Sumber Tentang Metode-metode Baru. Jakarta: UIP, 1992.

Document:

Undang-Undang Republik Indonesia Nomor 25 Tahun 2012 tentang Perkoperasian

Undang-Undang Republik Indonesia Pasal 15 UU Nomor 12 Tahun 1992 tentang Perkoperasian

Undang-Undang Republik Indonesia Pasal 24 ayat 4 UU Nomor 12 Tahun 1992 tentang Perkoperasian

Permendagri nomor 41/2012 Pasal 1 